VOX PATRUM $25(2005)$ t. 48

Alicja STĘPNIEWSKA

(Lublin, KUL)

\title{
ŚWIĘTA EMMELIA - MATKA BAZYLEGO WIELKIEGO I GRZEGORZA Z NYSSY
}

Wśród wielu wybitnych kobiet starożytności chrześcijańskiej, obok dziewic i męczennic, wymienić należy również matki, które wydały na swiat wielkich i sławnych synów. Najbardziej znanymi na Zachodzie były niewątpliwie św. Monika - matka św. Augustyna ${ }^{1}$ oraz św. Sylwia - matka Grzegorza Wielkiego $^{2}$, na Wschodzie natomiast św. Emmelia i św. Nonna - matki Ojców Kapadockich, a także św. Antuza - matka św. Jana Chryzostoma. Najwięcej wiadomości pochodzi od ich synów, którzy, choć nie napisali oddzielnych biografii, w swych pismach poświęcili matkom mniej lub więcej miejsca, pozostawiając dla potomnych trwały slad ich życia.

W artykule zostanie ukazana postać św. Emmelii, matki m.in. dwóch świętych: Bazylego Wielkiego i Grzegorza z Nyssy, a źródłem informacji będą przede wszystkim Listy $^{3}$ pierwszego z nich iŻywot św. Makryny ${ }^{4}$ drugiego oraz mowa pogrzebowa, przyjaciela rodziny, Grzegorza z Nazjanzu Na cześć Bazylego ${ }^{5}$.

Cóż wiemy o domu rodzinnym Emmelii? Bardzo niewiele. Przypuszczalnie pochodziła z Kapadocji ${ }^{6}$. Ojciec jej prześladowany przez cesarza (prawdopo-

${ }^{1}$ Por. L.E. Bougaud, Sw. Monika, thum. anonimowe, Brody - Lwów 1910; A. Trapè, Sant'Agostino - mia madre, Roma 1983; A. Stępniewska, „Gdzie ty, tam i on”. Sen św. Moniki, matki św. Augustyna (Confessiones III 11, 12-20), VoxP 8 (1988) z. 14, 125-132. 363-373.

2 Por. A. Stępniewska, Sylwia-matka papieza Grzegorza Wielkiego, VoxP 23 (2003) t. 44-45,

${ }^{3}$ Por. Basilius, Epistolae, PG 32, 220-1112, thum. K. Krzyżaniak: Sw. Bazyli, Listy, Warszawa 1972.

${ }^{4}$ Por. Gregorius Nyssenus, Vita S. Macrinae, PG 46, 959-1000 lub wyd. P. Maraval, SCh 178, Paris 1971, thum. W. Kania: Sw. Grzegorz z Nyssy, Życie sw. Makryny, AnCra 3 (1971) 383-404.

${ }^{5}$ Por. Gregorius Nazianzenus, Oratio 43, PG 36, 493-605 lub wyd. J. Bernardi, SCh 384, Paris 1992, 116-307, przekład polski: Sw. Grzegorz z Nazjanzu, Mowy wybrane, Warszawa 1967, 476-523.

${ }^{6}$ Por. Gregorius Nazianzenus, Oratio 43, 3, PG 36, 497BC, SCh 384, 122-124, Mowy wybrane, s. 478: „Ileż to chwały przysporzyliby mu w naszych oczach jego przodkowie [...]. Niejedno opowiadanie podsuwa nam Pont o rodzinie jego ojca, w niczym nie ustępujące cudownym legendom pontyjskim z zamierzchłych czasów, które wypełniają prozę historyczną i poezję. Wielu też opowiadań dostarcza ta moja kraina, sławna Kapadocja [...]. Dzięki tym opowiadaniom możemy porównać ród matki z rodem ojca". Nieliczne współczesne informacje o św. Emmelii, zamieszcza- 
dobnie Licyniusza) został stracony, a majątek skonfiskowany ${ }^{7}$. Nie wiadomo, w jakich okolicznościach zmarła jej matka. Została więc sierotą w młodym wieku. Narażona na liczne niebezpieczeństwa postanowiła wyjść za mąż. Młodszy jej syn, Grzegorz, późniejszy biskup Nyssy, pisze o małżeństwie rodziców:

„Matka odznaczała się cnotą, kierując się we wszystkim wolą Bożą i kochając niewinność i czystość, tak że nawet wyjść za mąż musiala wbrew woli. Ale straciwszy obojga rodziców, dla swej piękności narażona na grożące ze strony ubiegających się o jej rękę (a wielu ich było i urzeczeni jej pięknością chcieli ją porwać) niebezpieczeństwo grzechu, dla ochrony życia wybrała sobie znanego $\mathrm{z}$ cnoty i poważnego męża",

Tak rozpoczęła Emmelia trudy życia codziennego z Bazylim, odznaczającym się religijnością i wielką szlachetnością. Pochodził ze sławnego rodu, którego rodzina (podobnie zresztą jak Emmelii) była prześladowana i zmuszona do ucieczki w góry, gdzie ukrywała się około 7 lat ${ }^{9}$. Wśród obywateli był cenionym adwokatem i podziwianym za swą wiedzę. W Poncie miał prawdopodobnie katedrę retoryki. Słynął bowiem z umiejętności wymowy przewyższając innych w tej dziedzinie. Znany w całym Poncie był nazywany „wspólnym dla wszystkich nauczycielem cnoty"10.

ne przeważnie przy jej mężu Bazylim zob. Acta Sanctorum Mai VII, Paris 1867, 238-242 (De sanctis coniugibus Basilio et Emmelia); J. Baudot - L. Chaussin, Vies des Saints et des bienheureux, vol. V, Paris 1947, 586-587 (Saints Basile et Emmélie); A Dictionary of Christian biography, literature, sects, and doctrines, ed. W. Smith - H. Wace, II, London 1880, 112 (Emmelia); R. Janin, Basile, DHGE VI 1075; A. Amore, Basilio ed Emmelia, BS II 949; K. Lutosławski, Wychowanie Ojców Kapadockich, AK 3 (1911) t. 5, 219-230, 326-333, spec. 221-230 (św. Emmelia), również oddzielna odbitka, Włocławek 1911; Ch. Joest, Basilius der Große (330-379) und seine Familie, ErA 78 (2002) 141-146.

7 Por. Gregorius Nyssenus, Vita Macrinae 20, SCh 178, 206, Kania s. 395-396: „dziadka ze strony matki na skutek niechęci cesarza pozbawiono życia i całe jego mienie dano innym. Nikt jednak nie cieszyl się wtedy większym imieniem niż oni”. Prawdopodobnie w późniejszym czasie odzyskali majątek, skoro, jak wspomina Grzegorz, jego matka Emmelia placiła „trzem władcom podatki, gdyż jej majątek był rozproszony w wielu krajach" (tamże, 5, SCh 178, 160, Kania s. 389).

8 Tamże 2, SCh 178, 144, Kania s. 387.

9 Por. Gregorius Nazianzenus, Oratio 43, 5-6, PG 36, 500C-501A, Mowy wybrane, s. 479-480: „Przodkowie Bazylego ze strony ojca, którym po przebyciu całej drogi wierności owe okoliczności [prześladowanie za Maksymina] przyniosły piękne ukoronowanie życia [...]. Uciekają w lasy gór pontyjskich - a jest tam wiele gęstych i rozległych borów - zabierając kilku tylko ludzi do pomocy w ucieczce oraz w zdobywaniu żywności [...] jak dhugo tam byli - podobno ucieczka ich przeciągnęła się niemal do siedmiu lat, a nawet trochę dłużej [...] do jakiej rozpaczy nędzne i niezwykłe dla delikatnych organizmów warunki życia, nękające pod gołym niebem mrozy, upały i deszcze, brak przyjaciól, towarzyszy i obcowania z ludźmi, musiały doprowadzić tych, których otaczała liczna swita i oznaki czci".

10 Por. Gregorius Nyssenus, Vita Macrinae 21, SCh 178, 210, Kania s. 396: „Chlubimy się w tym życiu, iż pochodzimy ze sławnego rodu i szlachetnych rodziców. Ojciec w tych czasach słynął wśród obywateli i w sądach jako człowiek bardzo wyksztalcony. Choć swą wymową przewyższał 
Mimo iż jej małżeństwo zawarte było $\mathrm{z}$ rozsądku, można jednak sądzić, że wybór Emmelii był chyba trafny. Grzegorz z Nazjanzu wyznaje, że było ono zgodne, oparte na żywej wierze, cieszące się wśród otoczenia głębokim szacunkiem, pełne poświęcania się dla innych. Jednak ,za cnotę największą i najgodniejszą sławy - uważał on - posiadanie dobrych dzieci"11.

Doczekali się bowiem licznego potomstwa - czterech synów: Bazylego, Naukracjusza, Grzegorza i Piotra oraz pięć córek, z których znamy tylko imię najstarszej - Makryny ${ }^{12}$. Czworo $\mathrm{z}$ nich powiększyło grono świętych, a mianowicie Bazyli Wielki - bp Cezarei Kapadockiej ( $†$ 379), Grzegorz - bp Nyssy († 394), Piotr - bp Sebasty i Makryna.

Ognisko domowe tworzyła przede wszystkim matka. To ona poświęcała się bez reszty wychowaniu swych dzieci w duchu głębokiej pobożności i odpowiedzialności. Dbała, aby w domu panowała harmonia, wzajemna miłość i zgoda. Grzegorz z Nazjanzu zwrócił uwagę na zgodność jej imienia z postawą życiową. Emmelii bowiem, jak pisze, zostało nadane już wcześniej imię, „które ją okreś-

innych (a znana ona była daleko), to jednak nie przekroczyla granic Pontu - wystarczyło mu sławy w ojczyźnie"; zob. Amore, Basilio ed Emmelia, BS II 949.

11 Por. Gregorius Nazianzenus, Oratio 43, 9, PG 36, 504D-505A, SCh 384, 132, Mowy wybrane, s. 481: „Nie mniejszym tytułem do chwały bylo małżeństwo jego [Bazylego] rodziców. Oboje cieszyli się jednakowym szacunkiem oraz walorami zewnętrznymi. Można by wprawdzie przytoczyć wiele innych charakterystycznych momentów, jak karmienie żebraków, goszczenie obcych, oczyszczanie duszy przez wstrzemięźliwość, podatek z majątku poświęcony Bogu; [...] ja jednak za cnotę największą i najgodniejszą uważam posiadanie dobrych dzieci”.

12 Istnieją rozbieżności odnośnie do liczby dzieci Emmelii. Syn Grzegorz z Nyssy w dwóch miejscach podaje, że było ich dziewięcioro (por. Vita Macrinae 5, SCh 178, 158, Kania s. 389: „A miała matka czterech synów i pięć córek”, tamże, 20, SCh 178, 206, Kania s. 396: „ich majątek stosownie do liczby dzieci znów na dziewięć częsci został podzielony"), innym razem przytaczając słowa swej umierającej matki wymienia ich dziesięcioro (tamże, 13, SCh 178, 184-186, Kania s. 392-

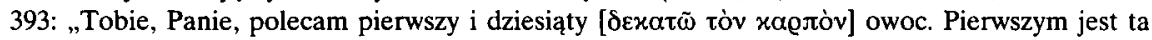

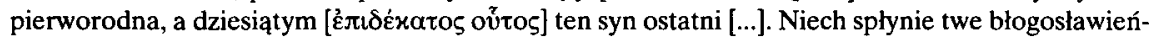

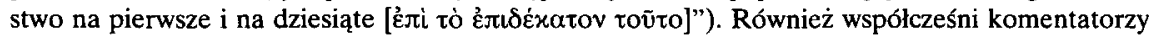
pism Grzegorza z Nyssy nie są pod tym względem zgodni. Większość z nich (por. J.E. Pfister, A biographical note: the brothers and sisters of St. Gregory of Nyssa, VigCh 18:1964, 108-113; M. Aubineau, Introduction-biographie, w: Grégoire de Nysse, Traité de virginité, SCh 119, Paris 1966, s. 35, n. 6; P. Maraval, Grégoire de Nysse, Vie de sainte Macrine, SCh 178, Paris 1971, s. 159 n. 3) a wcześniej już Suda w X wieku (Lexicon, Genève 1619, 539B), M.L. de Tillemont (Mémoires pour servir à l'histoire ecclésiastique des six premiers siècles, IX, Venice 1732, 7), W. Smith H. Wace (A Dictionary of Christian biography, s. 761), W.K.L. Clarke (St. Gregory of Nyssa, The Life of St. Macrina, London 1916, 7), J. Quasten (Patrologia, II, Casale 1969, 206) uważa, że było ich dziesięcioro, inni zaś, mniej liczni, choć równie wybitni, jak np. A. Puech (Histoire de la littérature grecque chrétienne, III, Paris 1930, 237, 397), podaje dziewięcioro. Niezgodnosć tę już w relacji samego Grzegorza z Nyssy, który chyba dobrze wiedzial, ile ma rodzeństwa, badacze wyjaśniają, że jedno $z$ dzieci Emmelii, prawdopodobnie po Makrynie a przed Bazylim [niektórzy pragną nawet odgadnąc jego imię: Nicefor], zmarlo we wczesnym wieku, tak że faktycznie, gdy matka umierała i dzieliła majątek, bylo ich dziewięcioro (por. Pfister s. 112-113; Maraval, SCh 178, s. 159, n. 3 i s. 187, n. 1 ). 
lało, lub też będącej taką, jakie imię jej nadano, ponieważ nosiła zgodnie

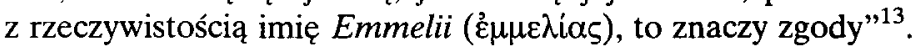

Pierworodnym dzieckiem Emmelii i Bazylego była Makryna. Nosiła imię po babce ze strony ojca, której życie, otoczone aureolą świętości, pełne wyrzeczeń i cierpień podczas prześladowań, było wzorem nie tylko dla najbliższej rodziny, ale i dalszego otoczenia ${ }^{14}$. Należy również wspomnieć, że Emmelia, krótko przed urodzeniem córki, miała sen. Ujrzała -

„postać nadludzkiej piękności, która dała dziecku imię Tekla, taką czcią otaczane przez dziewice. Trzykroć to powtórzywszy, postać znikła i sprawiła jej lekki poród, tak że zbudziwszy się zobaczyła matka przed sobą w rzeczywistości to, co widziała we śnie. Takie oto było tajemnicze imię dziecka"15.

Posłuszna więc woli Bożej nadała córce drugie imię - Tekla, wskazane jej we śnie.

Emmelia, mimo zatrudnionej piastunki, sama starała się zajmować zwłaszcza religijnym wychowaniem córki według wzorów, jakie obowiązywały w chrześcijańskich arystokratycznych rodzinach Małej Azji. W miarę dorastania uczyła dziewczynkę podstawowych zajęć praktycznych oraz etycznego postępowania i życiowej mądrości. Chroniła ją przed „niepożądaną” literaturą pogańską, a szczególnie gorszącymi komediami i drastycznymi scenami z tragedii. Podstawę wiedzy zapewniającej właściwą formację religijno-moralną stanowiło Pismo Swięte, a zwłaszcza Księga Mądrości. Matka stopniowo zaznajamiała córkę z pięknem i głęboką mądrością płynącą z Psalmów. Makryna z czasem dobrze poznała Psalmy -

„korzystając z nich - jak pisze Grzegorz - częściami stosownie do okoliczności: gdy wstawała $\mathrm{z}$ łóżka i rozpoczynała pracę, gdy odpoczywała, brała posilek i odchodzila od stołu, gdy szła do tóźka i wstawała do modlitwy, miała zawsze przy sobie psałterz jakby drugiego towarzysza, który jej nigdy nie opuszczał"16.

Podobny model wychowawczy wprowadzający w początkowe życie religijne był stosowany przez Emmelię również wobec pozostałych dzieci. Najstarszy

${ }^{13}$ Gregorius Nazianzenus, Oratio 43, 10, PG 36, 505C lub SCh 384, 134, Mowy wybrane s. 482.

14 Por. Gregorius Nyssenus, Vita Macrinae 2, SCh 178, 142-144, Kania s. 387: „słynęła w rodzinie Makryna, matka naszego ojca, która w czasie prześladowań stanęła w obronie Chrystusa. Jej to wlaśnie imię dali rodzice dziecku. Wiedziała o nim tylko ona i najbliżsi". Podobnie rolę babki Makryny w religijnym wychowaniu dzieci, również i siebie, podkreślał Bazyli, por. Epistola 204, 6, PG 32, 752C, Krzyżaniak s. 387: „Jakiż bardziej oczywisty dowód mógłby przemawiać za naszą wiarą niż ten, że zostaliśmy wychowani przez bogobojną babkę [...] wielebną Makrynę? Dzięki niej poznaliśmy wypowiedzi świątobliwego Grzegorza [Cudotwórcy], które zachowała ona $\mathrm{z}$ ustnego przekazu; strzegla ich sama i nas, małego jeszcze chłopca kształciła i wychowywała według zasad pobożności"; zob. tenże, Epistola 210, 3.

${ }^{15}$ Gregorius Nyssenus, Vita Macrinae 2, SCh 178, 146, Kania s. 387-388; por. F. Lanzoni, Il sogno presago della madre incinta nella letteratura medievale e antica, AnBol 45 (1927) 225-261.

${ }^{16}$ Tamże, 3, SCh 178, 148-150, Kania s. 388; por. Maraval, Introduction, SCh 178, 49-52 (éducation). 
syn, Bazyli Wielki, z ogromną wdzięcznością powie po latach, że wszystkie zasady wiary wszczepione przez matkę i babkę jeszcze w dzieciństwie, zachował na zawsze w sercu, jak się do tego szczerze przyznaje w liście do biskupa Eustacjusza z Sebasty:
„Nigdy nie miałem błędnych wyobrażeń Boga i nie zmieniłem moich przekonań, by przyjąć naukę zasłyszaną później. Pojęcie Boga, jakie od dzieciństwa przejąłem od świątobliwej mej matki i babki Makryny, zachowałem bez zmian i zabiegałem o jego pogłębienie. Nie przechodziłem bowiem od jednych poglądów do innych, kiedym już posiadł pełne rozeznanie rozumowe, ale doskonaliłem tylko przeka- zane mi przez nie zasady wiary"17.

Emmelia dzięki swym zaletom i rozwadze cieszyła się szacunkiem i autorytetem wśród swych dorosłych dzieci. Zaniepokojona niewłaściwą postawą syna Bazylego Wielkiego, który powrócił właśnie do Pontu po kilkuletnich studiach odbytych w sławnych ośrodkach naukowych - Cezarei, Bizancjum i Atenach - w sposób stanowczy, ale taktowny próbuje nakłonić go do zmiany postępowania, wskazując, że życiowa mądrość nie polega na wywyższaniu się ponad innych, lecz na właściwie pojętej pokorze wobec darów danych mu przez Opatrzność. Matka bowiem, kiedy ujrzała Bazylego:

„pysznego ze swej wymowy i wiedzy, gardzącego tymi, co się wznieśli na wysokie stopnie, i patrzącego $z$ góry nawet na samych urzędników cesarskich, starała się go zaraz pozyskać dla ideału życiowej mądrości w wyrzeczeniu się światowych zaszczytów, jakie płyną ze sławy wymowy, obraniu ręcznej pracy i pełnego ubóstwa, w poświęceniu się cnocie" $"$.

Również później, gdy tenże Bazyli razem z przyjacielem Grzegorzem z Nazjanzu podjęli (ok. 360 r.) anachoreckie życie na pustyni pontyjskiej, oddając się surowym postom i samotnej kontemplacji, Emmelia, choć aprobowała ich ascetyczny sposób życia, to wzywała ich do roztropności i umiaru, a nawet powrotu do normalnego pobożnego życia, w czym faktycznie znalazła posłuch. Dziękuje jej za to później Grzegorz z Nazjanzu nazywając ją „wielką

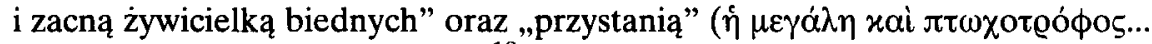

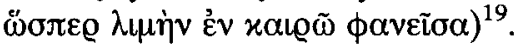

Utrwalanie i pogłębianie więzów rodzinnych było bardzo ważnym elementem wychowawczym wypracowanym przez Emmelię. Odpowiedzialność, a także posłuszeństwo wobec rodziców dorosłych już dzieci były czymś naturalnym

${ }^{17}$ Basilius, Epistola 223, 3, PG 32, 825C-828A, Krzyżaniak s. 253.

${ }^{18}$ Gregorius Nyssenus, Vita Macrinae 6, SCh 178, 162, Kania s. 389-390.

19 Por. Gregorius Nazianzenus, Epistola 5, PG 37, 29A, tłum. J. Stahr, POK 15, 9: „I gdyby ta wielka, ta zacna żywicielka biednych - matka twoja - nie była nas na czas wyrwała, ukazawszy się jak przystań miotanym bałwanami; już dawno byloby po nas i nie tyle chwalono by nas, ile litowano się nad nami za wiernośc dla Pontu". 
wypływającym nie tylko z obowiązku, ale przede wszystkim z miłości do nich. Prośba matki stanowiła jakby nakaz moralny, któremu nie można było się przeciwstawić. Grzegorz z Nyssy wspomina, że kiedy został wezwany przez matkę na uroczystość przeniesienia relikwii czterdziestu męczenników z Sebasty do kościoła w pobliżu Ibory nawet nie dopuszczał myśli, iż mógłby nie spełnić jej życzenia, chociaż w tym czasie było to dla niego wyjątkowo trudne $\mathrm{e}^{20}$.

Drugim przykładem takiej postawy był brat Naukracjusz, który, poruszony łaską Bożą, rozdał swój majątek i rozpoczął życie w samotności oraz ubóstwie w ustroniu nad rzeką Irys, gdzie w założonym przez siebie przytułku opiekował się ubogimi i chorymi starcami, zdobywając dla nich pożywienie. On też starał się - jak pisał Grzegorz -

„zadośćuczynić życzeniom matki, słuchając ją, gdy mu co kiedy poleciła zrobić, nadając w ten sposób swemu życiu odpowiedni kierunek, nie tylko przez wysiłki opanowując swą młodość, lecz i w trosce o matkę podążał do Boga prostą drogą przykazań. Upływał już rok piąty, jak oddał się mądrości, uszczęśliwiając tym matkę, gdyż z jednej strony swe życie zdobił cnotą, a z drugiej wszystkie siły swe oddal matce" 21 .

Należy jednak zaznaczyć, że Emmelia wraz z mężem Bazylim w sprawach zasadniczych potrafili uszanować wolę dzieci. Tak było w wypadku Makryny, która, po śmierci wybranego jej przez ojca młodzieńca, nie wyraziła zgody na małżeństwo ze starającymi się o jej rękę, mimo prób czynionych przez rodziców, nakłaniających ją do zmiany decyzji. Argumenty córki przyjęli z pełnym zrozumieniem. Postanowiła ona bowiem żyć w dziewictwie przy matce, tłumacząc:

„iż jest rzeczą złą i nierozumną przestać kochać raz przez ojca wyznaczonego na męża a oglądać się za innymi, skoro wszak z natury małżeństwo jest jedno, jak urodzenie i śmierć jest jedna!"22.

Matka, mając Makrynę przy sobie, mogła stworzyć właściwą ochronę dla jej duchowych i religijnych aspiracji ${ }^{23}$.

${ }^{20}$ Por. Gregorius Nyssenus, Oratio in quadraginta martyres, PG 46, 784-785: „Kiedy bowiem mieliśmy obchodzić pierwsze święto $z$ okazji przeniesienia relikwii i przenieść urnę do świętego kościoła, moja matka (której życie tak było zjednoczone z Bogiem, że każde święto uroczyście obchodziła), rozkazała mi przybyć i wziąć udział w uroczystościach. Ja tymczasem bylem daleko, jeszcze mlody i w świeckim stanie, i jak to się zazwyczaj zdarza w nagłym wypadku, zajęty różnymi sprawami; z przykrością więc i w swoim nierozsądku przyjąłem to polecenie mając trochę za złe matce, że nie odlożyła tego na inną porę i odrywa mnie przez to od różnych zajęć, a w dodatku sprowadziła mnie wcześniej, niż się zaczęto gromadzić. Udałem się więc do niej".

21 Tenże, Vita Macrinae 8, SCh 178, 168, Kania s. 390.

22 Tamże, 5, SCh 178, 154-158, Kania s. 389; por. Maraval, Introduction, SCh 178, 44-46.

${ }^{23}$ Por. tamże, 5, SCh 178, 156-160, Kania s. 389: „Nawet na chwilę nie odstępowała matki. Stąd jej matka zaznaczała często, że inne dzieci nosiła wprawdzie długo w łonie, ja jednak nosi ze sobą zawsze i wszędzie. Wspólne życie z córką nie było dla niej ciężarem, a to tym bardziej, iż 
Życie Emmelii nie pozbawione było jednak kłopotów oraz bolesnych rozstań z najbliższymi. Śmierć męża Bazylego i wydanie na świat syna Piotra (w latach 341-345) - „który był ostatnim owocem jej bólów, synem i sierotą; bo gdy przyszedł na świat ojciec już był pożegnał się z tym życiem"24 - uczyniło Emmelię bezradną wobec trosk i obowiązków, jakie na nią spadły. Podporą i pocieszycielką w tych trudnych chwilach stała się Makryna, która, aby odciążyć matkę, zaraz po urodzeniu się Piotra:

„wzięla go jako piastunka, sama go wychowywała, dała mu nawet całe wyższe wykształcenie, udzielając już jako dziecku świętych wiadomości, nie pozwalając mu oddawać się innym próżnym zajęciom. Stając się dla dziecka wszystkim, ojcem, nauczycielem, wychowawcą, matką, doradcą, uczyniła go takim człowiekiem, że, nim przekroczyl dzieciństwo, już jako młodzieniec wszedł na wysoki stopień filozofii," ${ }^{25}$.

To jednak nie koniec cierpień Emmelii. Musiała udźwignąć jeszcze jeden cios: śmierć ukochanego syna Naukracjusza. Była to śmierć nagła, nie wywołana żadną chorobą, i jak przypuszczał jego brat Grzegorz z Nyssy, spowodowana w wyniku zasadzki przeciwnika podczas połowu ryb. Kiedy zawiadomiono o tym nieszczęściu Emmelię, była zdruzgotana:

,zlamana na duszy, o mało nie umarła. Upadła z bólu, jak upada ugodzony ciosem bohater. W tym nieszczęściu ujawniła się moc ducha wielkiej Makryny. Pokonując cierpienie, okazała się niezwyciężoną, stając się podporą matki, swą dzielnością i siłą podnosząc ją z glębi bólu do męstwa. W ten sposób zwyciężyła matka cierpienie, nie dopuszczając do siebie niczego, co nieszlachetne" ${ }^{26}$.

Dzięki córce przetrwała i przezwyciężyła ból po stracie syna. Przypominają się tu słowa Grzegorza z Nazjanzu, który m.in. powiedział, że największym i najwspanialszym darem dla rodziców są dobre dzieci ${ }^{27}$. Takim właśnie darem dla Emmelii była córka Makryna.

zastępowała jej ona służące. Obie się uzupełniały i wyręczały, pierwsza pielęgnowała duszę dziewczyny, druga zaś ciało matki, nie tylko każdy jej rozkaz spełniając, lecz także chleb własnoręcznie przygotowując. Nie uważała jednak tego za główne zajęcie, ale gdy swe ręce uświęciła pobożnymi ćwiczeniami, czynila zadość potrzebom życia i swą domową pracą przygotowywała matce żywność. Pomagała jej też we wszystkich kłopotach. [...]. Ponieważ matka była zaprzątnięta rozlicznymi troskami (ojciec już nie żył), dzieliła córka z nią trudy, lżejszym jej przez to czyniąc ciężar cierpienia. Pod kierunkiem matki prowadzila się nienagannie, jej oczyma ustawicznie strzeżona, sama równocześnie stając się matce wzorem do tego samego celu, do życiowej mądrości, utwierdzając ją w czystym i doskonałym życiu".

${ }_{24}$ Tamże, 12, SCh 178, 180-182, Kania s. 392; o dacie urodzin Piotra i śmierci męża zob. Maraval, Introduction, SCh 178,48 , n. 2.

${ }^{25}$ Tamże, SCh 178, 182, Kania s. 392.

26 Tamże, 9-10, SCh 178, 170-172, Kania s. 391.

${ }^{27}$ Por. wyżej nota 11. 
Emmelia po usamodzielnieniu się dzieci i zapewnieniu im przyszłości postanowiła resztę życia spędzić $\mathrm{z}$ dala od ziemskich trosk tego świata. Obie $\mathrm{z}$ córką Makryną udały się pod Neocezareę i w rodzinnym majątku w Annisach nad rzeką Irys, w pobliżu Ibory, założyły klasztor-pustelnię, w pobliżu którego przez pięć lat przebywał również syn Naukracjusz. Miejsce to także często odwiedzali Bazyli i Grzegorz z Nazjanzu ${ }^{28}$.

„Trudno jest słowami oddać jej gorliwość, wysoką ascezę i umartwienie we dnie i w nocy [...]. Nie było między nimi gniewu, nienawiści, wywyższania się, znikła spośród nich duma i rozgłos, pycha i próżność. Rozkosze znajdowały we wstrzemięźliwości, chlubę w tym, że nie były znane, ubóstwo poczytywały za bogactwo, ziemskie dostatki za pył, który strzepywały z ciała, wszelkie doczesne zajęcia miały sobie za nicość, dbały tylko o rzeczy Boże i o ustawiczną modlitwę, śpiew psalmów nie ustawał we dnie i w nocy, praca byla dla nich zarazem wypoczynkiem" ${ }^{29}$.

Emmelia doczekawszy późnej starości umiera w Annisach, prawie 30 lat po śmierci męża, w 373 r. na rękach dwojga dzieci - córki Makryny i syna Piotra ${ }^{30}$. W ostatniej godzinie swego ziemskiego życia przywołuje w myślach wszystkie nieobecne dzieci, każde $z$ nich wymieniając $z$ imienia i przekazuje im swoje błogosławieństwo:

„W swej miłości pamiętała i o tych, które były daleko, aby żadne nie było bez błogosławieństwa. W modlitwie polecała Bogu zwłaszcza przy niej obecne. Siedzące zaś po obu stronach łóżka objęła ręką i w ostatnich słowach tak się modliła: «Tobie, Panie, polecam pierwszy i dziesiąty owoc. Pierwszym jest ta, pierworodna i dziesiątym ten syn ostatni. Ty masz do nich prawo i Twoim są darem. Niech spłynie Twe błogosławieństwo na pierwsze i na dziesiąte!» Myślała przy tym o córce i o synu. A gdy kończyła błogosławić, kończyła i życie, poleciwszy jeszcze dzieciom, by jej ciało przenieśli do ojcowskiego grobu"31.

Ani Grzegorz z Nyssy, który opisał odejście matki, ani Bazyli Wielki nie mogli być przy jej śmierci, gdyż był to rok, kiedy panował najcięższy głód, odkąd sięgała ludzka pamięc $c^{32}$, a jako odpowiedzialni pasterze Kościoła, musieli zaopiekować się głodującymi.

${ }^{28}$ O lokalizacji Annis i Ibory por. Basilius, Epistolae 3, 2; 14, 2; 223, 5; G. de Jerphanion, Ibora - Gazioura?, „Mélanges de la Faculté Orientale” 5 (1911) 333-354; H. Leclercq, Ibora DACL VII 4-9; Maraval, Introduction, SCh 178, 38-43 (literatura i mapa).

29 Gregorius Nyssenus, Vita Macrinae 11, SCh 178, 176, Kania s. 391.

${ }^{30}$ Odnośnie do dokładnej jej daty toczy się dyskusja: mogła ona nastąpić albo między wielkim głodem (368-369) a wyświęceniem Bazylego na biskupa (tj. 369 lub 370), albo w pierwszych miesiącach 371 r., jakby na to wskazywał pochodzący z czerwca 371 r. 30. list Bazylego, wspominający śmierć matki jako świeże wydarzenie. Por. na ten temat argumentację: Maraval, Introduction, SCh 178, 56-57 (La mort d'Emmélie).

31 Gregorius Nyssenus, Vita Macrinae 13, SCh 178, 184-186, Kania s. 392-393.

32 Por. Gregorius Nazianzenus, Oratio 43, 34, PG 36, 541-544 lub SCh 384, 200, Mowy wybrane, s. 497. 
Bazyli głęboko przeżył śmierć matki. Rozstanie z nią odchorował i boleśnie opłakiwał, mimo iż miał blisko czterdzieści lat. Chociaż matka właśnie nauczyła go, że woli Bożej należy poddać się z pokorą, a do Boga prowadzi tylko jedna droga - przez życie ziemskie, to jednak trudno mu było ogarnąć w samotności ten bezmiar cierpienia. W liście pisanym 371 roku Do Euzebiusza, biskupa Samosat żali się:

„Teraz zaś za grzechy moje utraciłem matkę, jedyną pociechę, jaką miałem w życiu. Nie drwij sobie ze mnie, że w tak posuniętym już wieku boleję nad mym sieroctwem, ale zechciej mnie zrozumieć, iż rozstania się z tą duszą znieść mi nie sposób, bo wśród dóbr, jakie mi jeszcze zostały, nie widzę niczego, co móglbym z nią porównać”33.

Słowa te wyrażają wielką miłość syna do matki. To ona, zawsze czujna, była jego duchem opiekuńczym i ona od najmłodszych lat prowadziła go ku najwyższym szczytom doskonałości i świętości.

Jego przyjaciel Grzegorz z Nazjanzu, który znał dobrze Emmelię, gdyż bywał w jej domu i słuchał jej rad jako roztropnej matki, na wieść o śmierci poświęcił jej dwa epitafia:

„Zmarła Emmelion. Któżby to pomyślał? Tyle

I tak udanych dzieci na ten świat wydała.

Synów, córki, w małżeństwie, czy też w wolnym stanie,

Jak żadna $\mathrm{z}$ kobiet matka, szczęśliwa i płodna.

Trzech $z$ nich świetnych kapłanów, jedną zaś kapłana

Żonę, a resztę bliskich jakby wojsko zbożnych".

„Podziw mnie wziął, gdym patrzyl na tyle dzieci Emmalion

Tak udanych, ten cały skarb dostojnego lona,

Ale wiedziałem, że ona krew zacna, dobro Chrystusa,

Emmelijon, więc rzekłem: «Nie dziw to - z takiego korzenia!

To jest zbożności dar święty, o ty, najlepsza wśród kobiet,

Chwał twych dzieci to jedno, czego pragnęłas gorąco»" ${ }^{34}$.

Więzy rodzinne, na które matka kładła tak wielki nacisk i które tak pielęgnowała, przetrwały wśród rodzeństwa również po jej śmierci. Wzruszającym ich przykładem jest scena spotkania Grzegorza z Makryną po ośmiu latach rozłąki. Grzegorz prześladowany i wygnany z ojczyzny przez cesarza Walensa powrócił właśnie do kraju i postanowił odwiedzić siostrę, nie przypuszczając, że zastanie ją na łożu śmierci ${ }^{35}$.

33 Basilius, Epistola 30, PG 32, 313A, Krzyżaniak s. 71.

34 Gregorius Nazianzenus, Epitaphia 54 (161) - 55 (162), PG 38, 37-38, thum. J. Łanowski: Sw. Grzegorz z Nazjanzu, Epigramy, WST 5 (1992) 49-50.

${ }^{35}$ Por. Gregorius Nyssenus, Vita Macrinae 16-22, Kania s. 394-395. 
Oboje utracili już ojca i matkę oraz dwóch braci - Naukracjusza i Bazylego Wielkiego, biskupa Cezarei Kapadockiej. Teraz Grzegorz mial świadomość, że traci także siostrę. Makryna w tej ostatniej godzinie przed śmiercią przywołuje chwile $z$ dawnych lat, opisując wszystko, co utkwiło w jej pamięci o domu rodzinnym. Wspominając rodziców stwierdziła, że życie ich znane było wśród ludzi nie tyle $\mathrm{z}$ bogactwa, co z błogosławieństwa Boga, który darzył ich swoją laską ${ }^{36}$.

Imiona Emmelii i jej męża Bazylego zostały po raz pierwszy oficjalnie włączone w 1586 r. przez Cezarego Baroniusza ( $†$ 1607) do Martyrologium Rzymskiego pod dniem 30 maja $^{37}$, choć już wcześniej w tym dniu zdaje się je prawdopodobnie w pewien sposób wspominać powstałe w połowie $\mathrm{V}$ wieku Martyrologium Hieronimiańskie ${ }^{38}$; w tym dniu są również liturgicznie wspominani na Wschodzie, a także w ostatnio zreformowanym Martyrologium Rzymskim, opublikowanym po Soborze Watykańskim II, gdzie czytamy:

„W Cezarei Kapadockiej świętych Bazylego i Emmelii, którzy byli rodzicami świętych biskupów Bazylego Wielkiego, Grzegorza z Nyssy i Piotra z Sebasty oraz świętej Makryny Dziewicy. Ci bowiem święci małżonkowie w czasach cesarza Galeriusza Maksymiana wygnani przebywali na pustyni pontyjskiej, a po prześladowaniu zostawiwszy dzieciom w dziedzictwie przykład swoich cnót zasnęli w pokoju" 39 .

Mimo iż kult rodziców trzech wybitnych Ojców Kapadockich nie rozwinął się szerzej w Kościele, nie stworzył uroczystych świąt, zwyczajów, a nawet ich własnej ikonografii, to jednak pozostają oni, zwłaszcza matka Emmelia, patronami wszystkich rodzin chrześcijańskich.

${ }^{36}$ Por. tamże, 20, SCh 178, 206, Kania s. 395-396.

37 Por. Martyrologium Romanum, ed. H. Delehaye, Bruxellis 1940, 215-216, n. 6, thum. P. Turbak: Martyrologium Rzymskie, Kraków 1967, 157-158: „W Cezarei w Kapadocji św. Bazylego i jego żony świętej Emmelii, rodziców świętych biskupów Bazylego Wielkiego, Grzegorza z Nyssy i Piotra biskupa Sebasty oraz świętej Makryny panny. Święci ci małzonkowie zmuszeni za panowania Galeriusza Maksymiana iśc na wygnanie mieszkali na pustyni Pontu. Po skończonym prześladowaniu odpoczęli w pokoju uczyniwszy dzieci swoje spadkobiercami cnót swoich".

38 Por. Martyrologium Hieronymianum (X Kal. Iun.), ed. H. Delehaye, Bruxellis 1931, 268: „Iuliani Felicis Montanae Ianuariae Emeliae Nonnae Almeridae Asti Basilei episcopi Victorii [...]". Komentarz do takiej możliwości zob. tamże s. 269.

${ }^{39}$ Por. Martyrologium Romanum ex decreto sacrosancti oecumenici Concilii Vaticani II instauratum, editio typica, Typis Vaticanis 2001, s. 294 (30 V, n. 2): „Cesareae in Cappadotia sanctorum Basilii et Emmeliae, qui parentes fuerunt sanctorum episcoporum Basilii Magni, Gregorii Nysseni et Petri Sebastensis atque sanctae Macrinae virginis. Hi vero sancti coniuges tempore Galerii Maximiani imperatoris extorres facti Ponticas solitudines incoluerunt et post persecutionem filiis suarum virtutum heredibus relictis in pace quierunt". 


\section{DIE HL. EMMELIA - DIE MUTER DES HL. BASILIUS DES GROSSEN UND DES HL. GREGORIUS VON NYSSA}

\section{(Zusammenfassung)}

Der Aufsatz stellt die Person der hl. Emmelia dar, die die Mutter von zehn Kindern war, u.a. des hl. Basilius des Grossen und des hl. Gregorius von Nyssa. Die Quelle aller Informationen über sie sind „Die Briefe” des hl. Basilius des Grossen, „Das Leben der hl. Makrina” des Gregorius von Nyssa und die Leichenrede des hl. Gregors von Nazianz „Zu Ehren des Basilius”, der zum Freund dieser Familie gezählt war. Im Aufsatz wird die Rolle der Mutter bei der Gründung des Heimes betont, die für christliche Erziehung ihrer Kinder sorgte und ihnen entsprechende religiösmoralische Formation versicherte. Ein wichtiger Faktor im Emmelias Erziehungsprogramm war auch die Vertiefung und Befestigung der Bindungen zwischen erwachsenen Kindern. 